\title{
Investigation of Properties of Asphalt Concrete Containing Boron Waste as Mineral Filler
}

\author{
Cahit GÜRER ${ }^{1}$ *, Gülden Şirin SELMAN ${ }^{2}$
}

\author{
${ }^{1}$ Afyon Kocatepe University, Engineering Faculty, Department of Civil Engineering, A.N.S. Campus, 03200, \\ Afyonkarahisar/Turkey \\ ${ }^{2}$ Afyon Kocatepe University, Graduate School of Natural and Applied Science, Department of Civil Engineering, A.N.S. \\ Campus, 03200, Afyonkarahisar/Turkey \\ cross $^{\text {ref }}$ http://dx.doi.org/10.5755/j01.ms.22.1.12596
}

\section{Received 30 June 2015; accepted 09 December 2015}

\begin{abstract}
During the manufacture of compounds in the boron mining industry a large quantity of waste boron is produced which has detrimental effects on the environment. Large areas have to be allocated for the disposal of this waste. Today with an increase in infrastructure construction, more efficient use of the existing sources of raw materials has become an obligation and this involves the recycling of various waste materials. Road construction requires a significant amount of raw materials and it is possible that substantial amounts of boron-containing waste materials can be recycled in these applications. This study investigates the usability of boron wastes as filler in asphalt concrete. For this purpose, asphalt concrete samples were produced using mineral fillers containing $4 \%, 5 \%, 6 \%, 7 \%$ and $8 \%$ boron waste as well as a $6 \%$ limestone filler $(6 \% \mathrm{~L})$ as the control sample. The Marshall design, mechanical immersion and Marshall stability test after a freeze-thaw cycle and indirect tensile stiffness modulus (ITSM) test were performed for each of the series. The results of this experimental study showed that boron waste can be used in medium and low trafficked asphalt concrete pavements wearing courses as filler.

Keywords: boron waste, asphalt concrete, filler, engineering properties, Marshall design.
\end{abstract}

\section{INTRODUCTION}

In ancient times, Babylonians imported borax from the Far East for use in gold mining. Borax was first obtained from the Lake of Tibet. Boric acid was made from borax as early as the 1700s, and elemental boron was discovered in the early of the 1800s [1]. Today, manufactured boron is especially used in glass and fiberglass piping, nuclear power and agricultural industries, as well as in the production of fire insulation materials, detergents, and pharmaceuticals [2].

Turkey has the largest boron reserves in the world, unfortunately the huge amount of waste material produced during the purifying of boron containing ore is becoming an increasingly large problem. Using this waste as a source of raw materials for different applications will decrease the demand for both new sources of raw materials and waste storage areas. Furthermore, this recycling will contribute to protecting the environment [2,3-11].

A total of 400,000 tons of waste material is produced annually by the ETI MADEN Kirka Boron Works in Eskisehir from the concentrator and boron derivation plants producing 250.000 ton/year and 150,000 ton/year respectively [12]. First, the boron ore enters the washing section from the concentrator plant through preliminary sieving from a $6 \mathrm{~mm}$ sieve. After the ore that is less than 6 $\mathrm{mm}$ passes from the crusher through rollers the clay paste, which have no suitable grain size particle, are discarded. From the concentrator plants $2 \%$ of the waste is excavated mine ore that contains about $12-15 \% \mathrm{~B}_{2} \mathrm{O}_{3}$. The wastes produced from a synthesis of boron derivatives have a lower $\mathrm{B}_{2} \mathrm{O}_{3}$ content than the other waste products $(\sim 7-8 \%)$ [13].

Agricultural irrigation harms aquatic organisms and plants because of discharging the waste products of boron into the lakes and seas [14]. In the United States, certain measures are taken to protect the environment against the discharged waste. For example, improved cooling systems used in a borate refinery resulted in a $50 \%$ reduction in boron waste discharged to the nearby canal [15]. Such measures are essential in terms of not only preventing air, soil and water pollution, and environmental destruction but also reducing the need for waste storage areas and waste ponds as well as the related expenditures. In addition to the environmental gains, the waste material can be recycled to be used in the construction and maintenance of asphalt pavements, base and subbase construction providing economic benefits [2, 16, 17].

Various materials passed through number 200 sieves $(0.075 \mathrm{~mm})$ and added to asphalt concrete can be defined as filler. Stone, lime and cement powders can be used as mineral filler. The main function of mineral filler in asphalt concrete is to fill the void between the coarse and fine aggregate particles in order to increase the density thus allowing the asphalt concrete to gain impermeability and durability. Another important result of this process is the settlement of the fine aggregates which form a mortar by mixing with the asphalt. The thickness of the asphalt film differs depending on the amount of filler used in the asphalt concrete mixtures. The variation in consistency of the

\footnotetext{
* Corresponding author. Tel.: +90-532-7332225; fax: +90-272-2281422.

E-mail address: cgurer@aku.edu.tr(C.Gürer)
} 
mixture and the temperature can be reduced by using appropriate filler in the mixture [18]. Additionally, Gubler et al. [19] have indicated that small filler particles prevent oxygen diffusion through the asphalt.

The objective of this study is to undertake experiments to investigate the use of waste from boron derivation plants as filler in hot mix asphalt wearing courses. The results of this study have implications for reducing the demand for new quarries to provide road aggregates, new waste storage areas of boron mining industry and decreasing environmental deterioration due to pollution from boron waste.

\section{MATERIALS AND METHODS}

\subsection{Materials}

In this study, a limestone-originated aggregate was used as coarse and fine aggregate. The mineral filler was produced using the waste from a boron derivation plant, and a limestone mineral filler was used as the control sample $(6 \% \mathrm{~L})$. The boron waste was obtained from the ETI MADEN Kirka Boron Works and the 50/70 grade penetration asphalt was obtained from the Aliağa Refinery to be used as a binder. The rheological properties of the asphalt are shown in Table 1.

Table 1. Rheological properties of the asphalt

\begin{tabular}{|l|c|c|}
\hline Properties & Value & Standard \\
\hline Source & Aliağa/Turkey & - \\
\hline Penetration Grade & $50 / 70$ & - \\
\hline Penetration at $25\left({ }^{\circ} \mathrm{C}\right)$ & 61 & ASTM D5-06e1 \\
\hline Specific gravity & 1.039 & ASTM D70-09e1 \\
\hline Softening point $\left({ }^{\circ} \mathrm{C}\right)$ & 47 & $\begin{array}{c}\text { ASTM } \\
\text { D36/D36M-09 }\end{array}$ \\
\hline Loss on heating $(\%)$ & 2.0 & ASTM D6-95 \\
\hline Flash point, $\left({ }^{\circ} \mathrm{C}\right)$ & 290 & ASTM D92-05a \\
\hline $\begin{array}{l}\text { Ductility } \\
\left(5 \mathrm{~cm} / \text { min at } 25^{\circ} \mathrm{C}\right)\end{array}$ & $>100 \mathrm{~cm}$ & ASTM D113-07 \\
\hline Viscosity at $135^{\circ} \mathrm{C}$ & $0.409 \mathrm{~Pa} \mathrm{~s}$ & ASTM D4402-06 \\
\hline Viscosity at $165^{\circ} \mathrm{C}$ & $0.106 \mathrm{~Pa} \mathrm{~s}$ & \\
\hline
\end{tabular}

The properties of superior wear and durability are desirable in aggregates used in hot mix asphalt [7]. The wear and durability properties of the aggregate samples were determined through standard tests and the test results given in Table 2 show that the aggregate samples were within the specification limits (Table 2).

\subsection{Methods}

The experimental study consisted of three stages; characterization of waste material, testing the aggregate and testing the hot mix asphalt.

Characterization of Waste Material: This stage includes a Scanning Electron Microscope (SEM) investigation and a chemical analysis. A LEO 1430 VP model SEM device was used for the SEM analysis. The whole rock major and trace element analyses of filler samples were performed in ACME Analytical Laboratories (Vancouver) Ltd. The chemical composition of the waste, determined with inductively coupled plasma optical emission spectroscopy (ICP-OES model 3200 XL Perkin Elmer, USA).
Aggregate Tests: In this stage, tests were performed regarding specific gravity coarse, fine and filler aggregates, Los Angeles abrasion value, aggregate impact value, freezing-thawing, and \% loss of aggregate after freezingthawing.

Hot mix asphalt tests: In the third stage, the Marshall design test, mechanical Marshall immersion test, Marshall stability and flow tests after freezing and thawing cycle and indirect tensile stiffness modulus tests were performed. These tests are given in detail below.

Marshall design tests are performed in order to determine the optimum asphalt content for different aggregate mixtures. This method requires standard hot mix asphalt briquette samples $10 \mathrm{~cm}$ in diameter and $6.5 \mathrm{~cm}$ high. The preparation procedure is carefully specified, and involves heating (aggregates were heated to $165^{\circ} \mathrm{C}$, bitumen was heated to $160{ }^{\circ} \mathrm{C}$ ), mixing (used temperature controlled mixer), and compacting asphalt/aggregate mixtures by 75 blows from the Marshall hammer. Once prepared, the samples are subjected to a density-voids analysis and stability-flow tests using the U-test Marshall stability and flow test device. Based on the test results, the following charts were plotted; (1) stability versus asphalt content (\%), (2) bulk specific gravity versus asphalt content (\%), (3) voids filled with asphalt (VFA) versus asphalt content (\%), (4) voids versus asphalt content (\%), (5) flow versus asphalt content (\%) and (6) voids in mineral aggregates versus asphalt content (\%). The optimum asphalt content was determined from charts (1) to (4) as follows: asphalt content corresponding to the maximum stability; asphalt content corresponding to the maximum bulk specific gravity; asphalt content corresponding to the average of design limits of air voids in the total mixture (3-5\%); asphalt content corresponding to the 65 and $78 \%$ range of VFA.

The optimum asphalt content is determined by calculating the arithmetic mean of the four values. In order to check the results of the optimum asphalt content, Fig. 9 and Fig. 10 were used. The optimum asphalt content corresponding to the flow value should be between 2 and $4 \mathrm{~mm}$ and the optimum asphalt content corresponding to VMA should be between 14 and $16 \%$.

For the mechanical Marshall immersion test, the principles are based on the measurement of change in the mechanical properties of the compacted hot mix asphalt samples after being immersed in water bath at $60{ }^{\circ} \mathrm{C}$ for 48 hours. In this way, it is more feasible to determine, which mixture sample is more resistant to the effects of water. Accordingly, this test is an indirect measurement of stripping and they also give an idea of the adhesion properties of asphalt concrete samples [20].

For the Marshall stability and flow tests after freezing and thawing cycle, briquette samples with optimum bitumen content were subjected to a freeze-thaw cycle 5 times based on TS EN 1097-2 and the reports of some researchers [23].

After the cycles, the loss of Marshall stability values was determined. A NÜVE Climate Cabinet was used for the cycles. The indirect tensile - stiffness test (ITSM) is performed to determine the stiffness of asphalt concrete based on EN 12697-26 (2004) specification. 
Table 2. Properties of aggregate samples

\begin{tabular}{|c|c|c|c|c|}
\hline Samples & $\begin{array}{l}\text { Apparent specific } \\
\text { gravity, } \mathrm{g} / \mathrm{cm}^{3}\end{array}$ & $\begin{array}{l}\text { Bulk specific } \\
\text { gravity, } \mathrm{g} / \mathrm{cm}^{3}\end{array}$ & $\begin{array}{c}\text { Water } \\
\text { absorption, \% }\end{array}$ & Standard \\
\hline >Sieve number:4 (coarse aggregate) & 2.710 & 2.683 & 0.37 & ASTM C127-88 \\
\hline $\begin{array}{c}\text { Sieve number: } 4 \text { - sieve number:200 (fine } \\
\text { aggregate) }\end{array}$ & 2.699 & 2.671 & 0.65 & ASTM C128-88 \\
\hline Filler of boron waste & 2.608 & - & - & - \\
\hline Filler of limestone & 2.738 & & \multicolumn{2}{|c|}{-} \\
\hline Aggregate tests & Value & Limit & \multicolumn{2}{|c|}{ Standard } \\
\hline Los Angeles abrasion value, $\%$ & 22.4 & $<35$ & \multicolumn{2}{|c|}{ ASTM C 131-89 } \\
\hline Aggregate impact value, $\%$ & 8.9 & $<18$ & \multicolumn{2}{|c|}{ ASTM D3744/D3744M-11 } \\
\hline Loss of freezing-thawing, $\%$ & 0.52 & $<12$ & \multicolumn{2}{|c|}{ TS EN 1097-2 } \\
\hline Loss of resistance after freezing-thawing cycle, $\%$ & 29.6 & - & \multicolumn{2}{|c|}{ TS EN 1097-2 } \\
\hline Sieve number & Sieve, $\mathrm{mm}$ & Passing, \% & \multicolumn{2}{|c|}{ Lower-upper limits } \\
\hline $3 / 4^{11}$ & 19.0 & 100 & \multicolumn{2}{|c|}{100} \\
\hline $1 / 2^{11}$ & 12.5 & 92.0 & \multicolumn{2}{|c|}{$83-100$} \\
\hline $3 / 8^{11}$ & 9.5 & 80.0 & \multicolumn{2}{|c|}{$70-90$} \\
\hline Sieve number: 4 & 4.75 & 48.0 & \multicolumn{2}{|c|}{$40-55$} \\
\hline Sieve number:10 & 2.00 & 32.0 & \multicolumn{2}{|c|}{$25-38$} \\
\hline Sieve number:40 & 0.425 & 15.0 & \multicolumn{2}{|c|}{$10-20$} \\
\hline Sieve number: 80 & 0.180 & 10.5 & \multicolumn{2}{|c|}{$6-15$} \\
\hline Sieve number: 200 & 0.075 & 7.0 & \multicolumn{2}{|c|}{$4-10$} \\
\hline
\end{tabular}

The stiffness modulus is considered to be a measure of the ability of asphalt concrete pavement to distribute traffic load and is perceived to be most important performance characteristics of asphalt concrete. The stiffness modulus monitors the permanent deformations caused by the tensile and compressive stresses that cause fatigue cracks under the pavement due to traffic loads. The stiffness modulus obtained under uniaxial loading is generally taken as the ratio of the maximum displacement to the maximum tensile strain. The test was performed at $10^{\circ} \mathrm{C}$ and $20^{\circ} \mathrm{C}$ temperatures with a deformation control based on a period of $3000 \mathrm{~ms}$, five loads with a rise time of $124 \pm 2 \mathrm{~ms}$ using a infratest model universal test machine and the indirect tensile stiffness modulus is calculated with Eq. 1.

$S_{m}=\frac{L \cdot(v+0.27)}{D \cdot t}$,

where the $S_{m}$ is the indirect tensile stiffness modulus, MPa; $v$ is the Poison ratio $(0.35), L$ is the maximum value of the vertical load, $\mathrm{N} ; D$ is the average horizontal deformation and $\mathrm{t}$ is the average thickness of the sample, $\mathrm{mm}$ [20].

\section{RESULTS AND DISCUSSION}

\subsection{Waste material characterization}

To determine the characterization of the waste material, a chemical analysis and a scanning electron microscopy analysis were conducted. A LEO 1430 VP model SEM device was used for the SEM analysis. The whole rock major and trace element analyses of filler samples were performed in ACME Analytical Laboratories (Vancouver) Ltd.

\subsubsection{Results of the scanning electron microscopy analysis}

With the SEM analysis, the surface morphology of boron waste was determined and a qualitative analysis was performed. As a result of the measurements, the size of the crystals and pores were found to range from $358 \mathrm{~nm}$ and
$7736 \mu \mathrm{m}$ to $426 \mathrm{~nm}$ and $447 \mathrm{~nm}$ (Fig. 1 and Fig. 2), respectively. This may have resulted from the effect of the filler particle porosity of the material on asphalt absorption.

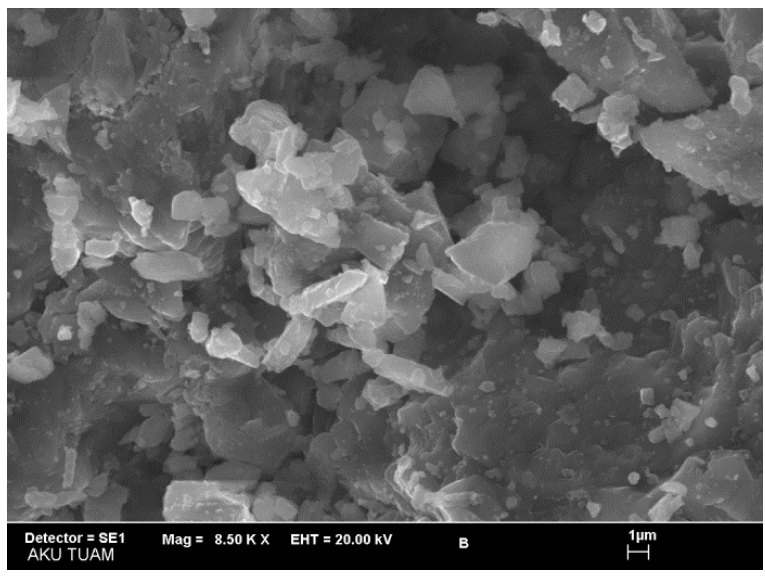

Fig. 1. SEM morphology of boron waste powder

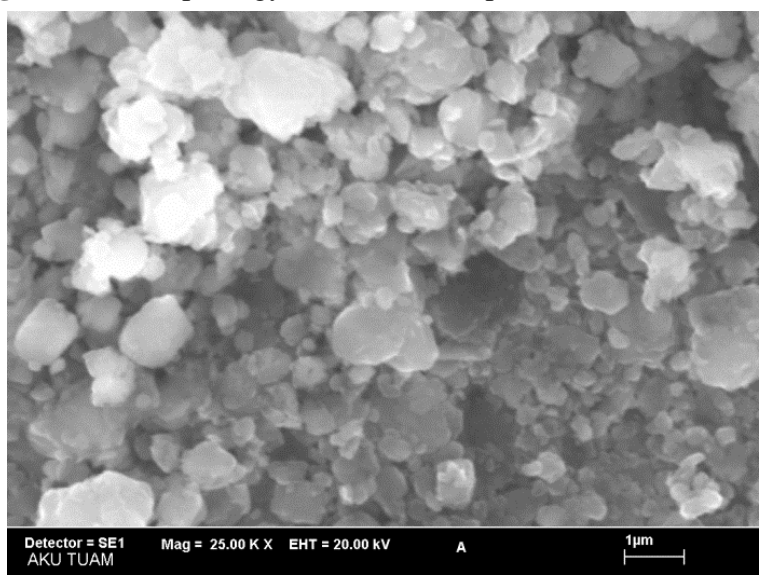

Fig. 2. Mineral crystals and their pores in the boron waste fillers

\subsubsection{Results of the chemical analysis}

A chemical analysis was performed on the waste obtained from boron derivation plants, and the results are 
given in Table 3. According to the results of the analysis, the material defined as clay paste mainly consists of siliceous, alumina and magnesium-containing compounds. The percentage of boron was determined as 12.20.

Table 3. Chemical composition of boron waste filler

\begin{tabular}{|c|c|}
\hline Component & Values, \% \\
\hline Loss of ignition & 32.2 \\
\hline $\mathrm{CaO}$ & 11.78 \\
\hline $\mathrm{SiO}_{2}$ & 15.41 \\
\hline $\mathrm{Al}_{2} \mathrm{O}_{3}$ & 1.51 \\
\hline $\mathrm{Fe}_{2} \mathrm{O}_{3}$ & 0.43 \\
\hline $\mathrm{MgO}$ & 13.62 \\
\hline $\mathrm{Na}_{2} \mathrm{O}$ & 7.92 \\
\hline $\mathrm{K}_{2} \mathrm{O}$ & 1.20 \\
\hline $\mathrm{P}_{2} \mathrm{O}_{6}$ & 0.02 \\
\hline $\mathrm{TiO}_{2}$ & 0.03 \\
\hline $\mathrm{MnO}_{2} \mathrm{O}_{3}$ & 0.01 \\
\hline $\mathrm{Cr}_{2} \mathrm{O}_{3}$ & $<0.002$ \\
\hline $\mathrm{B}_{2} \mathrm{O}_{3}$ & 12.20 \\
\hline Other trace elements & 3.67 \\
\hline $\mathrm{Sum}_{2}$ of & 100 \\
\hline
\end{tabular}

\subsubsection{Results of the hydrometer test}

Hydrometer tests were performed on the boron waste filler sample and the limestone control sample. Test results show that the boron waste filler sample was finer than the control sample. This resulted in an increase in the aggregate surface area and the optimum percentage of bitumen (see Fig. 3 and Fig. 4).

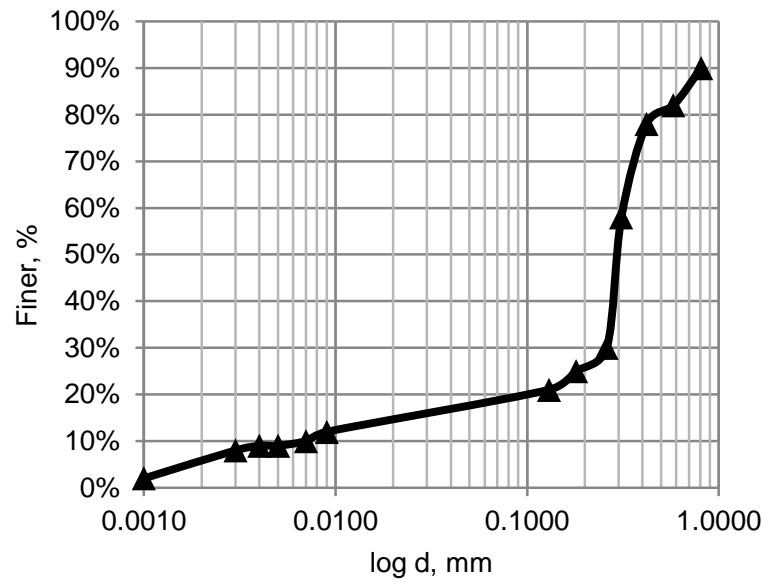

Fig. 3. Hydrometer test result of recycled boron waste filler

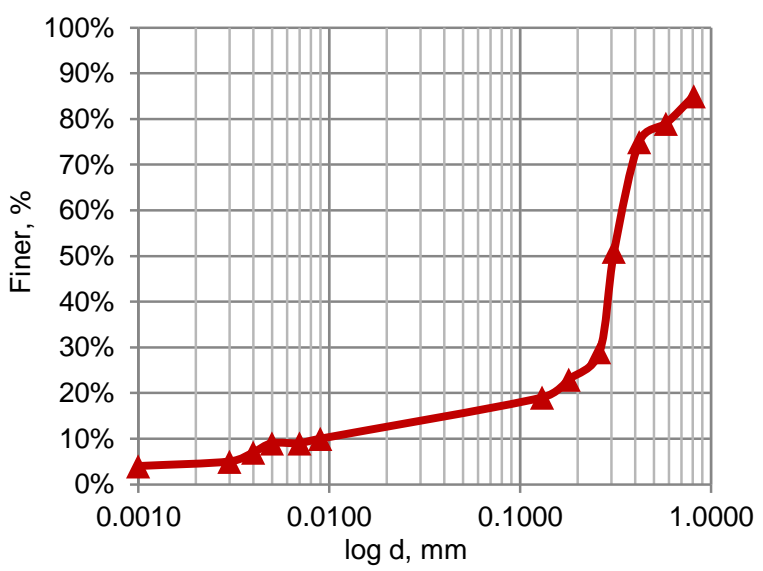

Fig. 4. Hydrometer test result of recycled limestone filler

\subsection{Results of the hot mix asphalt test}

\subsubsection{Results of the Marshall design test}

Hot mix asphalt samples were prepared using five different amounts of boron waste filler and the limestone control sample. Marshall designs were performed on each filler ratio to determine the variation in hot mix asphalt properties in relation to the ratio. Mixture samples were prepared for gradation in the middle of the Turkish Highway specification (TCK) curve of wearing courses, and as a result, three Marshall briquettes were obtained with the each of the asphalt ratios: $3.5 \%, 4.0 \%, 4.5 \%, 5.0 \%, 5.5 \%$ and $6.0 \%$.

Marshall stability-flow tests were performed on the samples, and their weights in water, air and surface drysaturated were measured. Furthermore, optimum asphalt ratios were separately calculated for each filler ratio. The optimum amounts of asphalt by weight were determined as; $5.43 \%, 5.04 \%, 4.80 \%, 5.16 \%, 4.99 \%$, and $4.70 \%$ for the filler additives containing $4 \%, 5 \%, 6 \%, 7 \%$, and $8 \%$ boron waste and the $6 \% \mathrm{~L}$, respectively. The correlation between the Marshall stability and asphalt content is given in Fig. 5.

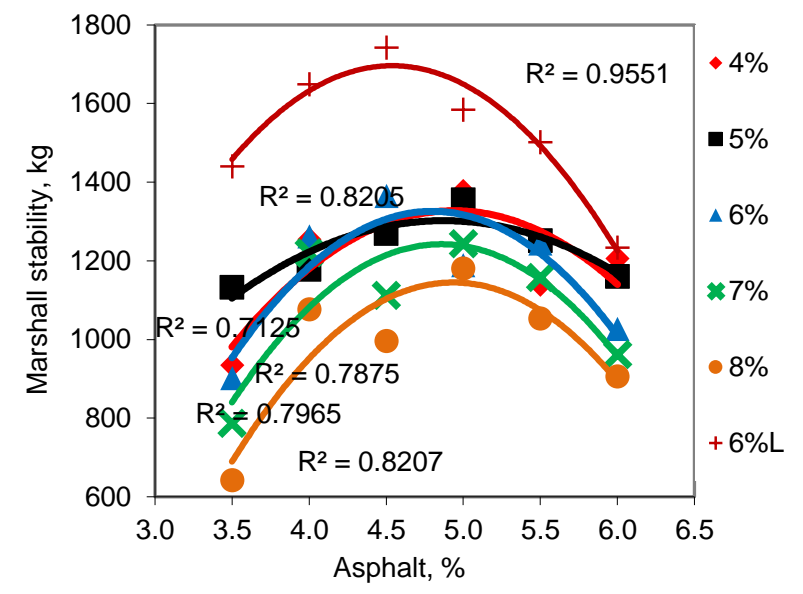

Fig. 5. Relationship between Marshall stability and percentage of asphalt

Marshall stability is one of the most important properties of hot mix asphalts [7]. It is the resistance of hot mix asphalt against the continuous dynamic loads with the long-term effects of static loads caused by vehicles, compression, tension, and shear forces that occur under accelerating or decelerating wheel effects [18]. According to the test results, when the amount of boron waste mineral filler by weight was more than $6 \%$, the maximum stability of the mixed samples was reduced. This reduction in the stability is mostly due to the decrease in asphalt film thickness with the increased amount of filler. However, control sample $(6 \% \mathrm{~L})$ had the highest stability value. The average maximum stability of samples of the $6 \% \mathrm{~L}$ series and boron waste series were determined as 1690 and $1220 \mathrm{~kg}$, respectively. The stability values of all samples were higher than the minimum specification limit $(750 \mathrm{~kg})$.

Another important property in hot mix asphalt is the density. Fig. 6 presents the relationship between bulk specific gravity and the percentage of asphalt. As the density of hot mix asphalt increases its physical properties such as durability and stability is improved. 


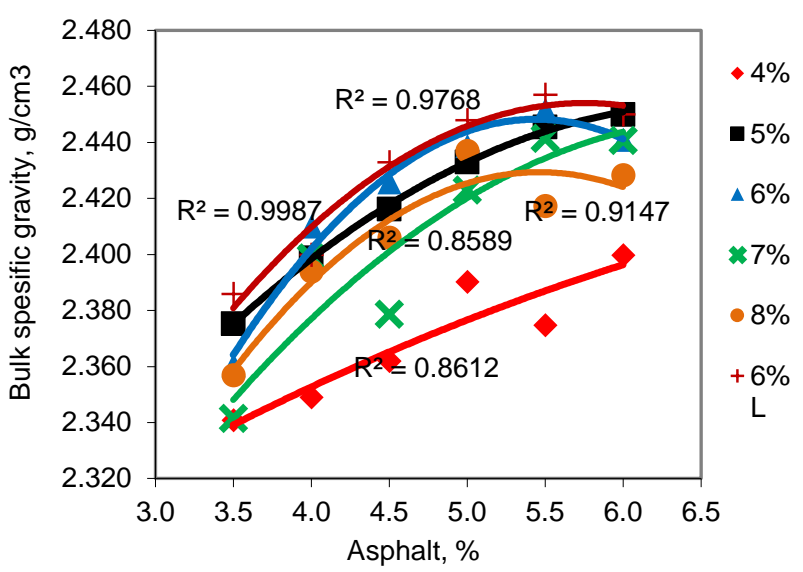

Fig. 6. Relationship between bulk specific gravity and percentage of asphalt

The highest specific gravity was obtained for the samples with the $6 \%$ boron waste and control fillers. The maximum specific gravities of the $4 \%, 5 \%, 6 \%, 7 \%$, and $8 \%$ boron waste samples and the $6 \% \mathrm{~L}$ control sample were found to be; 2.396, 2.452, 2.444, 2.440, 2.428 and $2.453 \mathrm{~g} / \mathrm{cm}^{3}$, respectively. The results show that the density value increases with the increased amount of filler. If the amount of filler is further increased, the film thickness of asphalt decreases. Therefore, the expected compaction cannot be obtained and the density of hot mix asphalt decreases. Furthermore, the specific gravity values of the $6 \%$ boron waste and $6 \% \mathrm{~L}$ control samples were similar to each other, thus indicating that the impermeability and durability properties of samples with boron waste filler are as good as the control samples. VFA is an important property in terms of providing resistance to raveling and environmental effects.

VFA controls plasticity, durability and friction coefficient of the mixtures and also provides a final asphalt coating around the aggregate particles. If the VFA is too low, the durability and stability of asphalt concrete is also weakened [18]. In the current study, the VFA values of samples with $4 \%, 5 \%, 6 \%, 7 \%$ and $8 \%$ boron waste fillers were found to be; $74.0 \% ; 80.0 \% ; 82.0 \% ; 78.0 \%$, and $70.0 \%$, respectively. However, the VFA of the $6 \% \mathrm{~L}$ control sample was determined as $77.0 \%$. In addition, the percentage of asphalt corresponding to $70 \%$ of the VFA value was used to determine the optimum asphalt content. According to the specifications of the Turkish State Highway Authority (TCK), the VFA value should be lower than $75 \%$. Fig. 7 gives the VFA values of all samples.

The TCK specifications of the highways suggest that the void content in asphalt concrete should be between $3 \%$ and $5 \%$. Increasing the upper limit of voids can decrease the stability and unit weight, which in turn increases permeability. A void value that is lower than the specification limit can lead to problems such as bleeding. Similarly, if the void value is higher than the limit, then it may result in a rapid increase in aging and permeability. On the other hand, since the volume of asphalt expands and fills the voids completely in hot mix asphalt causing deterioration of bleeding in the hot summer season, in the current study, a lower limit of void was determined in accordance with the specifications recommended.

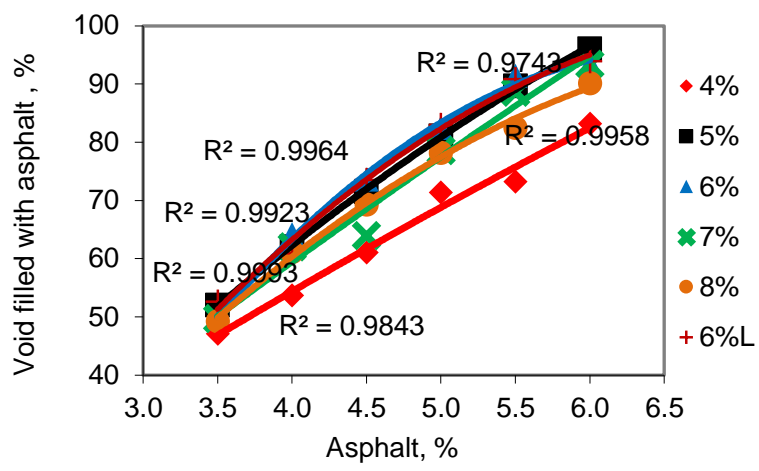

Fig. 7. Relationship between VFA and percentage of asphalt

For the hot mix asphalt samples containing $4 \%, 5 \%$, $6 \%, 7 \%$, and $8 \%$ boron waste mineral filler and the $6 \%$ limestone filler $(6 \% \mathrm{~L})$, the percentage of voids in relation to the optimum level of asphalt were found to be $3.9 \%$, $2.5 \%, 4.0 \%, 3.0 \%, 3.2 \%$ and $3.0 \%$, respectively. The test results showed that the percentages of void were within the specification limits except in the sample with $5 \%$ boron waste. The relationship between the percentages of void and asphalt is shown in Fig. 8.

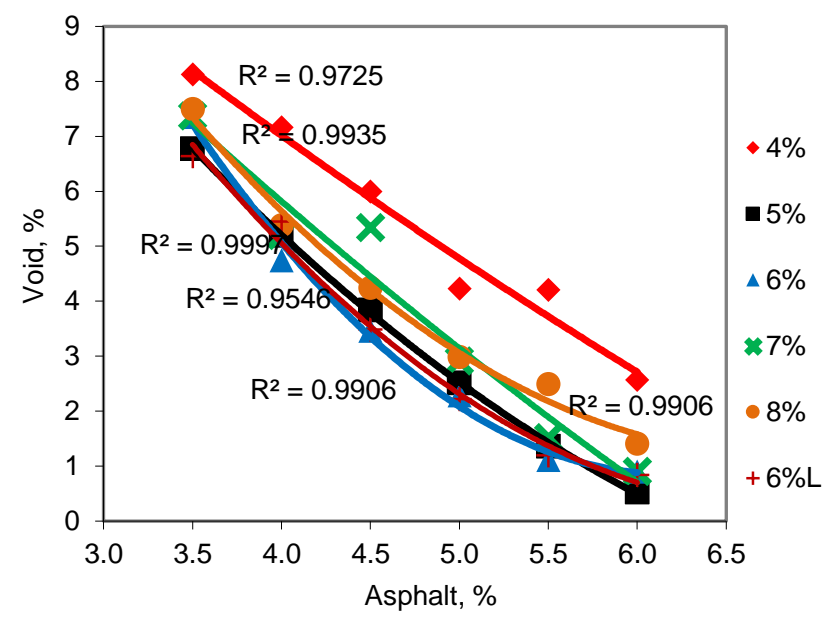

Fig. 8. Relationship between the percentages of void and asphalt

The Marshall flow values give an idea of the plasticity and flexibility of the hot mix asphalt samples [18]. The relationship between the flow values and the percentage of asphalt is given in Fig. 9.

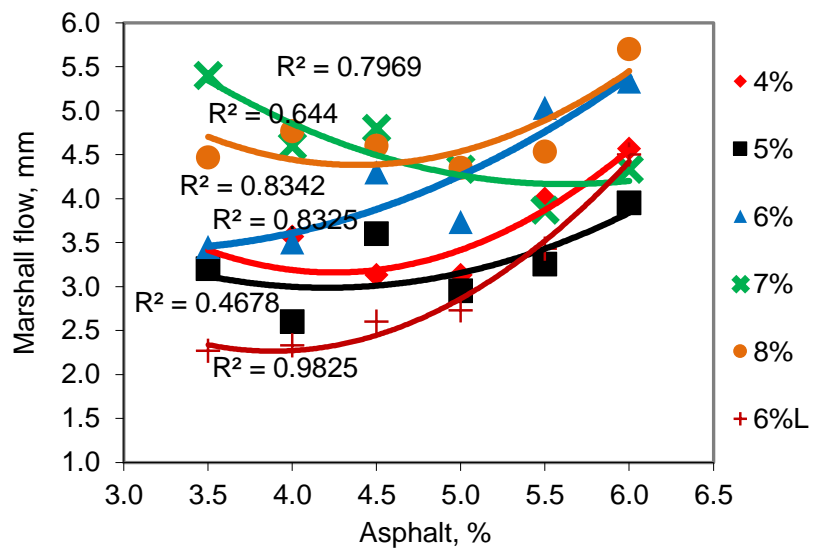

Fig. 9. Relationship between Marshall flow and percentage of asphalt 
According to the TCK specifications, the flow value should be between 2 and $4 \mathrm{~mm}$. The hot mix asphalt samples are expected to display brittle characteristics with the increased amount of filler. In this study, the flow values in relation to the optimum level of asphalt were found to be $3.9,3.1,4.1,4.2,4.5$ and $2.6 \mathrm{~mm}$ in hot mix asphalt samples with $4 \%, 5 \%, 6 \%, 7 \%, 8 \%$ boron waste mineral filler and the $6 \% \mathrm{~L}$ control sample, respectively. Based on these results, hot mix asphalt containing $5 \%$ boron waste produced the best result in terms of plastic deformation behavior.

VMA occur due to the total amount of asphalt film in hot mix asphalt aggregates and void volume. The level of voids in mineral aggregates is important in terms of the interlocking of aggregate particles as well as durability $[7,18]$. In the mixtures containing $4 \%, 5 \%, 6 \%, 7 \%, 8 \%$ boron waste fillers and the $6 \% \mathrm{~L}$ control sample, the percentage of VMA in relation to the optimum level of asphalt were found to be; $15.1 \%, 13.4 \%, 13.0 \%, 13.8 \%$, $13.8 \%$ and $13.2 \%$, respectively. The relationship between VMA and percentage of asphalt is presented in Fig. 10.

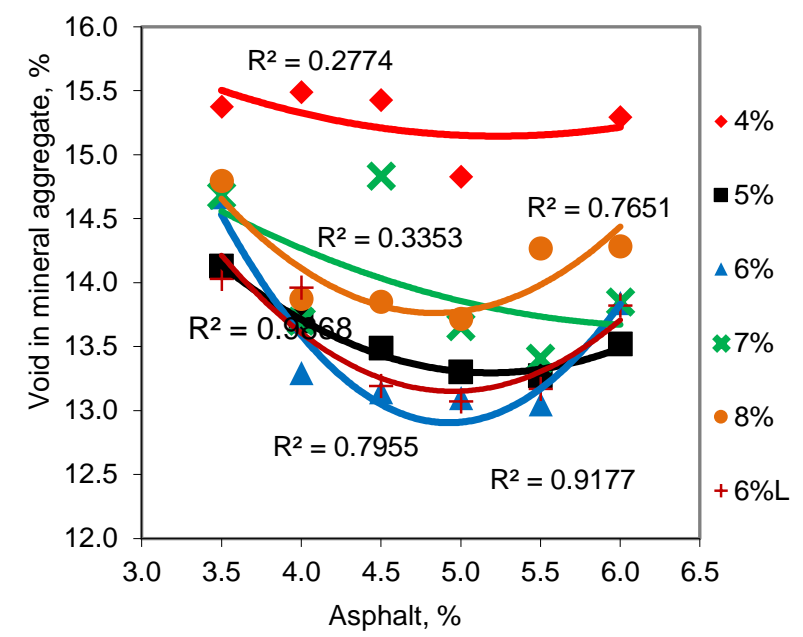

Fig. 10. Relationship between VMA and percentage of asphalt

The Marshall quotient, also known as the rigidity ratio, is defined as the ratio of the Marshall stability to the Marshall flow value of the hot mix asphalt. The relationship between the Marshall quotient and percentage of asphalt is given in Fig. 11. This ratio has been used for the estimation of the stiffness modulus of asphalt concretes [21, 22]. Çelik et al. [22] have reported that samples with a high Marshall quotient are fractured with high displacement. The Marshall quotient values for the optimum percentage of asphalt were found to be $3.6,4.2,4.3,2.8,2.6$ and $6.4 \mathrm{kN} / \mathrm{mm}$ in $4 \%$, $5 \%, 6 \%, 7 \%$ and $8 \%$ boron waste and $6 \% \mathrm{~L}$ control samples, respectively.

\subsubsection{Results of the mechanical Marshall immersion test}

This test was performed on each sample with optimum asphalt content, and the loss of Marshall stability $\left(L_{m s}\right)$ was calculated using the following Eq. 2:

$L_{m s}=\frac{S_{1}-S_{2}}{S_{1}}$.

After the samples were kept in a water bath at $60{ }^{\circ} \mathrm{C}$, their Marshall stability $\left(\mathrm{S}_{2}\right)$ was measured. The loss of
Marshall stability was calculated by subtracting from the highest Marshall stability value $\left(\mathrm{S}_{1}\right)$. Fig. 12 presents the loss of Marshall stability in all samples. The lowest loss in stability was obtained from the $6 \% \mathrm{~L}$ control sample followed by the $7 \%$ boron waste sample.

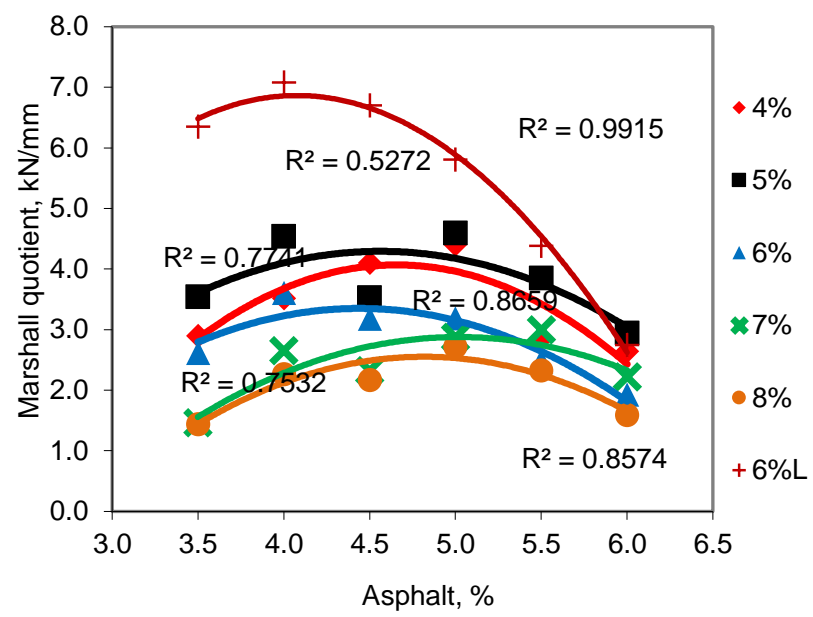

Fig. 11. The relationship between the Marshall quotient and percentage of asphalt

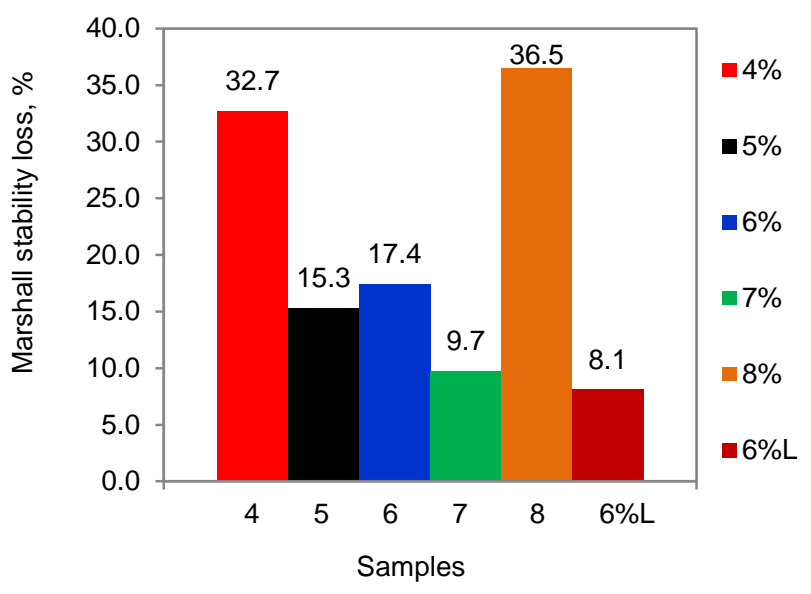

Fig. 12. Loss of Marshall stability

\subsubsection{Effects of the freeze - thaw cycle on the hot mix asphalt samples}

The service life of hot mix asphalt pavements is affected by many factors such as freezing-thawing, rain and snow. These factors may result in the loss of certain mechanical properties of hot mix asphalt pavements. Some researchers reported that the amount of water-induced damage was increased in hot mix asphalt samples with the increased number of freeze-thaw cycles [23]. The test results of the current study showed that the lowest loss of Marshall stability was observed in the control sample containing $6 \%$ limestone filler. However, the loss of Marshall stability obtained from the $6 \%$ boron waste sample was similar to that of the control sample. The loss of Marshall stability in all samples after the freeze-thaw cycle is given in Fig. 13.

\subsubsection{Indirect tensile stiffness modulus (ITSM) test}

The higher the stiffness modulus of asphalt concrete, the higher the resistance to permanent deformation is. The maximum stiffness modulus at $10{ }^{\circ} \mathrm{C}$ and $20{ }^{\circ} \mathrm{C}$ was obtained from the $6 \% \mathrm{~L}$ control sample as 15.1 and 
6.1 MPa, respectively. However, for the samples containing $4 \%, 5 \%, 6 \%, 7 \%$ and $8 \%$ boron waste fillers, the values of the stiffness modulus at $10{ }^{\circ} \mathrm{C}$ were determined as 10.8 , 13.7, 14.1, 14.0 and 13.6 MPa, respectively.

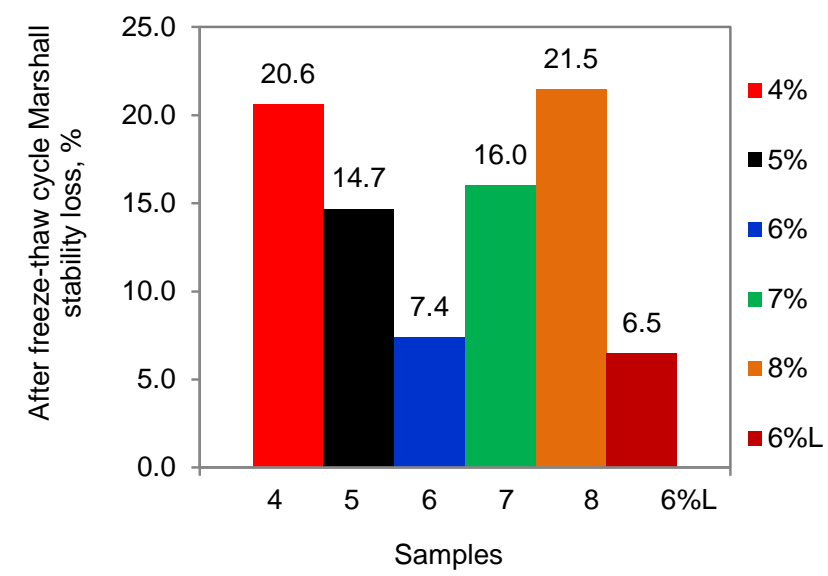

Fig. 13. Loss of Marshall stability (\%) after the freeze-thaw cycle

For the sample samples, the stiffness modulus at $20^{\circ} \mathrm{C}$ was found to be 3.3, 4.8, 5.9, 5.3 and 5.7 $\mathrm{MPa}$, respectively. This indicates that the stiffness modulus value of the $6 \%$ boron waste sample was very similar to that of the $6 \% \mathrm{~L}$ control sample (Fig. 14).

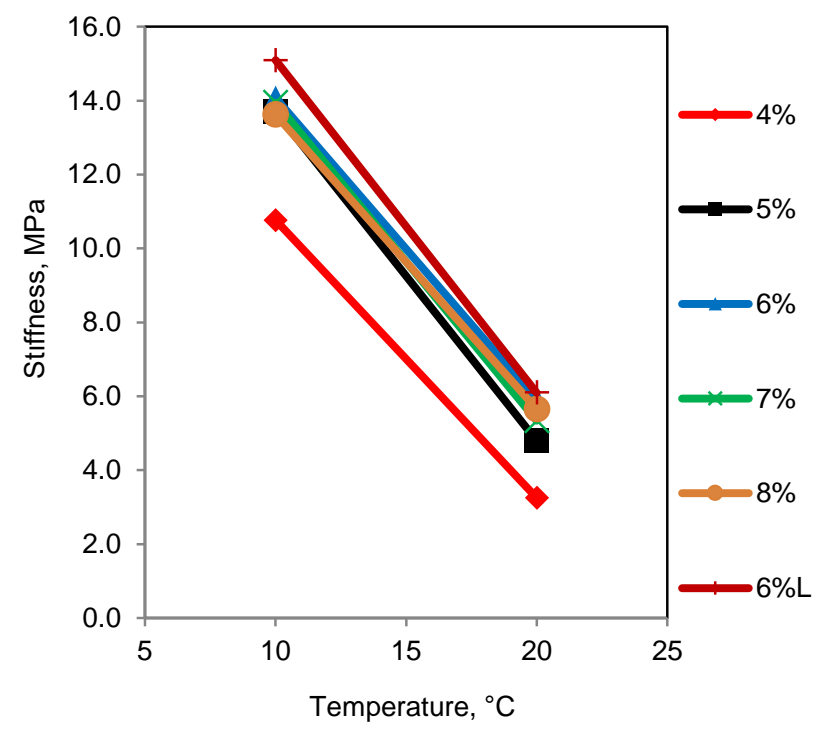

Fig. 14. Changing the stiffness modulus at $10{ }^{\circ} \mathrm{C}$ and $20^{\circ} \mathrm{C}$

\subsubsection{Determination of the optimum amount of boron waste filler}

The aim of this study was to investigate the usability of boron waste as filler in asphalt concrete. Hot mix asphalt samples were produced with five different filler ratios to determine the optimum percentage of filler, which exhibits the best behavior in asphalt concrete samples. According to the results of hot mix asphalt tests, the percentage of optimum boron waste filler was determined in 5 different series taking into account the following factors: filler percentage corresponding to:

- the highest Marshall stability value $\left(\mathrm{F}_{\mathrm{m}}\right)$;

- $\quad$ the highest density value $\left(\mathrm{F}_{\mathrm{d}}\right)$;

- $4 \%$ void value at lowest asphalt in $\%\left(\mathrm{~F}_{\mathrm{v}}\right)$;

- the lowest value of VMA $\left(\mathrm{F}_{\mathrm{ma}}\right)$;
- $3 \mathrm{~mm}$ of flow value $\left(\mathrm{F}_{\mathrm{f}}\right)$;

- $70 \%$ value of VFA $\left(\mathrm{F}_{\mathrm{fa}}\right)$;

- the lowest loss of Marshall Stability based on the results of the Mechanical Marshall Immersion test $\left(\mathrm{F}_{\mathrm{mi}}\right)$.

- the lowest loss of Marshall Stability after the freezethaw cycle $\left(\mathrm{F}_{\mathrm{ft}}\right)$;

- $\quad$ to the maximum stiffness modulus $\left(\mathrm{F}_{\mathrm{s}}\right)$.

The optimum percentage of filler was calculated to be $5.7 \%$ by taking the arithmetic mean of the factors according to Eq. 3 given below:

$F_{a}=\frac{F_{m}+F_{d}+F_{v}+F_{m a}+F_{f}+F_{f a}+F_{m i}+F_{f t}+F_{s}}{9}$.

\section{CONCLUSIONS}

Based on the results of laboratory tests and analyses, the following conclusions can be drawn:

The optimum amount of asphalt was calculated for each of the series, and all the values were found within the feasible limits.

The highest stability value was obtained from the $6 \% \mathrm{~L}$ control sample. The stability values from the highest to the lowest were from $6 \% \mathrm{~L}, 6 \%, 4 \%, 5 \%, 7 \%$ and $8 \%$. Therefore, it is considered that the hot mix asphalt sample with $6 \%$ filler is more durable to atmospheric conditions.

Fillers contribute to impermeability in hot mix asphalt pavement by increasing the density. In the current study, the highest density values were obtained from the sample with $5 \%$ boron waste filler additive. Therefore, the impermeability property of this sample was as good as that of the control sample $(6 \% \mathrm{~L})$. Using the waste boron filler in asphalt concrete resulted in lighter mixtures almost with higher percentage of voids compared with the corresponding mixtures containing ordinary limestone filler.

The surfaces of road pavements are exposed to the effect of water from several sources such as snow, rain, and freezing-thawing cycles. One of the most important characteristics favored in hot mix asphalt is to maintain its mechanical properties under the effect of water. The results of the mechanical Marshall immersion test show that hot mix asphalt with $7 \%$ boron waste filler additive are more durable against the effect of water and there was only a $9.7 \%$ decrease in Marshall stability.

Using boron waste as mineral filler in asphalt concrete caused a slight decrease in stiffness modulus values. However, it is considered that under the traffic load conditions, samples with $6 \%$ boron waste filler additive would behave as well as the $6 \% \mathrm{~L}$ control sample.

Based on the results of the hot mix asphalt test, the optimum amount of boron waste was $5.7 \%$ by weight. This means that boron waste filler exhibits the best behaviour when used at this ratio. However, to support the findings of this study, further research should be conducted on the field performance of asphalt concrete produced with a boron waste filler.

It can be concluded that boron waste can be successfully used in asphalt pavement wearing courses as filler, which will also contribute to the protection of the environment and provide economic benefits. 


\section{Acknowledgment}

Authors wish to thank the Scientific Research Projects (BAP) Coordination Department of Afyon Kocatepe University (Project Number:14.MUH.06) for financial support and Municipality of Afyonkarahisar for their helps.

\section{REFERENCES}

1. Moseman, R.F. Chemical Disposition of Boron in Animals and Humans Environmental Health Perspectives 102 1994: pp. $113-117$.

http://dx.doi.org/10.1289/ehp.94102s7113

2. Selman, G.Ş. Using Boron Wastes in Asphalt Pavements as Mineral Filler. M.Sc. Thesis, Graduate School of Natural and Applied Science, Afyon Kocatepe University: Afyonkarahisar, Turkey, 2013.

3. Ediz, N., Topçu, İ.B. Using Wastes of Kırka Borax Industry as Brick Material. Union of Chambers of Engineers and Architects of Turkey (TMMOB) Turkey Chamber of Civil Engineers- Branch of Ankara, Ankara, Turkey. Available from <http://www.e-kutuphane.imo.org.tr/pdf/13297.pdf>[in Turkish]. 1996. Accessed on August 01, 2014.

4. Emrullahoğlu, Ö.F., Emrullahoğlu, C.B. Effect of Etibor Kirka Boraks Tailing Addition on Properties of Floor Tile Body Proceedings of the 1st International Boron Symposium 2002: pp. 213-218 (in Turkish).

5. Kavas, T., Önce, G.I. The Usage Capacity of Etibor Kirka Borax Company's Wastes in The Production of Structural Bricks as a Flax Material Proceedings of the 1st International Boron Symposium 2002: pp. 219-223.

6. Uslu, T., Arol, A.I. Use of Boron Waste as an Additive in Red Bricks Waste Management 24 2004: pp. 217-220.

7. Akbulut, H., Gürer, C. Use of Aggregates Produced from Marble Quarry Waste in Asphalt Pavements Building\&Environment 42 (5) 2007: pp. 1921-1930.

8. Safiuddin, M., Jumaat, M.Z., Salam, M.A., Islam, M.S., Hashim, R. Utilization of Solid Wastes in Construction Materials International Journal of the Physical Sciences 5 (13) 2010: pp. $1952-1963$.

9. Yılmaz, M., Kök, B.V., Kuloğlu, N. Effects of Using Asphaltite as Filler on Mechanical Properties of Hot Mix Asphalt Construction and Building Materials 25 2011: pp. 4279-4286.

10. Jony, H.H., Al-Rubaie, M.F., Jahad, I.Y. The Effect of Using Glass Powder Filler on Hot Asphalt Concrete Mixtures Properties Engineering \& Technology 29 (1) 2011: pp. $44-57$.

11. Chen, M., Lin, J., Wu, S. Potential of Recycled Fine Aggregates Powder as Filler in Asphalt Mixture
Construction and Building Materials 2011: pp. 3909-3914.

12. Karasu, B., Kaya, G., Yurdakul, H. The Effect of Etibor Kirka Borax Company's Concentration and Derivation Wastes on the Properties of Wall Tile Bodies Proceedings of the 1st International Boron Symposium 2002: pp. $193-197$ [in Turkish].

13. Ediz, N., Özdağ, H. Processing of Tincal Ore with a SingleStage Helical Extractor, LUMA - Leeds University Mining Association 2001: pp. 93-101.

14. Aşkın, S. Using Boron Industry Wastes, Celal Bayar University Naturel Science Institute, Ph.D thesis 1998 [in Turkish].

15. Griffin, T.S. Rio Tinto borax's Initiative on Sustainable Development in Mining Operations Proceeding of the International Mining Congress and Exhibition of Turkey-IMCET 2003: pp. $375-379$.

16. Karadeniz, M. Ore Beneficiation Plant Waste Environmental Impact - Measures, General Directorate of Mineral Research and Exploration (MTA), Mining analysis and technologies (mat) department, Ankara, Turkey, 1996 [in Turkish]

17. Yaman, C., Maraşoğlu, M. Possible Using Area of Glassy Materials Produced from Boron Waste Proceedings of the 4th National Ceramic Congress 1998: pp. 97-102 [in Turkish].

18. Umar, F., A Ăar, E. Asphalt Pavements. Istanbul Technical University, Faculty of Construction Press, İstanbul, 1994 [in Turkish]

19. Gubler, R., Liu, Y., Anderson, D., Partl, M. Investigation of the System Filler and Asphalt Binders by Rheological Means Journal of Association of Asphalt Paving Technologists 68 1999: pp. 284-302.

20. Whiteoak, D. The Shell Bitumen Handbook, Shell Bitumen, England, 1990: pp. 179-180.

21. Lavin, P. Asphalt Pavements: A Practical Guide to Design, Production and Maintenance for Engineers and Architects. Spon Press, 2003.

http://dx.doi.org/10.4324/9780203453292

22. Çelik, O.N., Yonar, F., Ceylan, S. Filler Effects on Bituminous Hot Mixture Performance Proceedings of 7 th National Congress on Transportation 2007: pp. 196-204 [in Turkish].

23. Hunter, E.R., Ksaibati, K. Evaluating Moisture Susceptibility of Asphalt Mixes. Department Civil and Architectural Engineering. In: Report for United States Department of Transportation to the Mountain-Plains Consortium, University of Wyoming, Laramie, WY, 2002. 